Vol. 3, No. 01; 2020

ISSN: 2581-4664

\title{
IMPACT OF FOREIGN DIRECT INVESTMENT ON WEST AFRICAN ECONOMIC AND MONETARY UNION COUNTRIES ECONOMIC GROWTH
}

\author{
Settimba Muhamad, Qiao Yue and Settimba Aswillah \\ School Of Economics, Shandong University, Jinan.prchina,27-shanda North Road Jinan
}

$\underline{\text { http://doi.org/10.35409/IJBMER.2020.3146 }}$

\begin{abstract}
Analyzing the impact of FDI on the economic growth of developing countries has been the subject of extensive empirical research which termed as a description between developed and non- developing countries our study examines the impact of foreign direct investment on the economic growth of West African countries in a range of years using the random effects, fixed effects and Gaussian mixture model method. Empirical results show that FDI has no positive impact on economic growth across the sample. Recent years have had a the positively significant impact on the economic growth of West African member states and the effect of Foreign direct investment on the economic growth of four most significant countries in terms of gross domestic product and per capita gross domestic product is positive hence complements research explaining the economic growth of West African countries.
\end{abstract}

Keyword: foreign direct investment, GDP, economic growth.

\section{INTRODUCTION}

After the colonial domination and the independence of African States, the economic situation of most African countries, including West African countries, was fundamentally described by a lack of economic development in several sectors such as the social and cultural sector(Robinson \& Thierfelder, 2002). In the communication sector, the infrastructure was at the primary level, concerning education and health sector, there was also a lot of development plan to be done. Thus, countries initiated a substantial project for economic, cultural and social development. The most significant investments directed in agriculture and public infrastructure for food selfsufficiency, industry, and services with funds often borrowed, or in the form of development aid by developed countries. Faced with the insufficiency of national savings that can no longer satisfy their need for investment and the content of the massive debt, they found other alternatives as sources of financing for their economic development projects(African Development Bank Group, 2019). Among them: private capital, in other words, foreign direct investment, which will eventually become one of the preferred sources of external financing for borrowing on the financial markets and official development assistance. From 1950 to 1960, the majority of African countries, including WAEMU countries, considered foreign direct investment with great distrust, probably due to the sequels of colonization. FDI had a bad reputation, it's seen as the new form of domination through multinational corporations that 


\section{International Journal of Business Management and Economic Review}

Vol. 3, No. 01; 2020

ISSN: 2581-4664

suspected of being seeking the greatest can hinder social welfare by manipulating transfers, prices and creating economic enclaves(Zhang, 2001a). Currently, this mistrust of developing countries towards foreign direct investment has complemented evolved. Suspicious behaviors now replaced by a promotion policy aimed at attracting significant flows of FDI Oman (2000) and Dirk (2001). This total reversal of behavioral situation was partially made possible by the increasingly liberal global economic environment and the many commercial kinds of literature extolling the benefits of FDI. Indeed(Blundell, 2014), give FDI an essential place in economic development. Developing countries are now experiencing the benefits that foreign direct investors can bring to their economies. These African states want to emphasize the price mechanism as a factor of lessening the imbalances in the private sector by encouraging more foreign direct investment to solve the problematic debt situation(Moore \& Christin, 2013). Theoretically, when a country is facing a deficit in domestic resources, it will probably face an external debt that can be filled by an influx of foreign capital. At the macroeconomic level, this means that when public spending and domestic private investment exceed government revenues and domestic private savings, this internal deficit generates more imports than exports and thus creates an external debt (Berentsen, 1998). External financial institutions then solicited to fill this gap. The absorption of these can be done through domestic and foreign financing, but also through foreign direct investment.

1.1 Advantage on offers, resort offers many advantages over the first two decades when a foreign direct investment has a net inflow of foreign capital, and it is a form of market substitutable for the capital market, which is a less volatile source of international investment. Besides, among other benefits, it should be noted that foreign direct investment income is generally reinvested in the country, even though part of it repatriated. FDI brings new (technical) management methods, new organizational skills and access to the international market(De Melo, J. and Robinson, 1992). It provides a variety of products to residents. Also, if FDI increases productivity and this increase are not entirely appropriate for the investor, other actors in the productive national system and some economic agents will benefit directly. Domestic workers will help in terms of higher real wages; local households, in terms of lower prices and the government, in terms of higher tax revenues.

FDI also promotes technology transfer from developed to undeveloped countries, $\mathrm{Yu}$, Ning, Tu, Young Hong and Tan (2011). Foreign direct investment considered as one of the principal means of technology transfer. In doing so, it would contribute much more too economic growth than domestic private investment. The OECD (1998) has found that foreign direct investment has a more significant impact on economic growth than investment by local firms(Curea \& Ciora, 2013). The WAEMU countries have gone from aggressive behavior to foreign direct investment to the political attraction of multinationals. Also, given the level of implementation of the various WAEMU combined benefits integration projects in existing monetary and financial affairs, it has been sufficiently indicated that the motivations for FDI were stronger in this area. The geographical proximity and the cost of the cheap labor of the WAEMU countries are among the advantages to attract more investors. However, to take advantage of this growth potential, the host country's trade regime must be geared towards promotion.

\section{LITERATURE REVIEW}




\section{International Journal of Business Management and Economic Review}

Vol. 3, No. 01; 2020

ISSN: 2581-4664

During our research, we realized that most publications have focused on the impact of FDI on the growth of Africa's two principal regions: Africa Maghreb 1and sub-Saharan Africa. But the specific case of WAEMU there is few publications. The majority of authors have focused their research on the impact of foreign direct investment in developing countries. During our study, we also noted that a large number of studies had analyzed the relationship between FDI and economic growth in Africa. The primary interest of inquiry is whether FDI has an impact on a country's economic growth(MAS \& FSNWG, 2013). The implicit assumption is that economic growth naturally leads to improved well-being. Recently, some authors have set themselves the task of determining the role of countries in this market. In all cases, the answers to these questions mixed, but in most cases, the same positive effect of FDI inflows on economic growth in Africa observed. Sometimes contradictory answers, but which may be due to some methodological and conceptual factors, including the lack of complete harmonized data sets, variation in various definitions of FDI, and different econometric specifications.

\section{Definition of Foreign Direct Investment (FDI) and economic growth}

Foreign Direct Investment has discussed in several commercial disciplines. Thus, the theories of international trade, industrial organizations, the information economy, and development economics have focused on defining, understanding and analyzing both the determinants and effects of FDI(Gee, 1996). Each of these theories relied on a particular aspect of the international movements of firms. Some have understood FDI as a manifestation of the free flow of capital, others as an investment strategy. Moreover, while the capitalist view supports the idea that FDI is a driver of development, Marxist-inspired theories describe them as causes of marginalization of developing countries. Foreign Direct Investment (FDI) is a process where companies' resident in one country (parent or source) acquire ownership of assets in another country (host or host country) to control production, distribution or any other activity in this country (MAS \& FSNWG, 2013). The OECD defines foreign direct investment operations as follows: Foreign direct investment is an investment made by a resident entity of an economy to acquire a lasting interest in an enterprise resident in another economy. The implication of last interest with the existence of a relationship between direct investor and enterprise whereby the investor can exert a strong influence on management

The foreign investor doesn't need to have absolute control: the criterion applied is participation equal to $10 \%$ of the voting rights. This definition coincides IMF3 shows foreign investment characterized by the contribution of the international firm to decision-making in the local enterprise. This refers to the notion of control. For example, the World Development Report(Robinson \& Thierfelder, 2002) defines FDI by emphasizing the sustainability of the foreign firm's control over the local firm. The investment must have a long-term relationship reflecting a specific and evolving interest in the power of the company resident in the host country. The sustainability of this control is essential to the distinction between FDI and portfolio investment. Short-term profits motivate the latter and often for speculative reasons. The definition of these two financial institutions has assessed as IFM and OECD corresponds to our study framework. Although these countries have low labour costs and high rates of return on investment, they attract very little foreign direct investment. However, some African countries are still essential destinations for FDI(Davis, 2011). Economic Growth is the positive change in a country's activity, which is measured by changes in prices, production of goods and services, and 


\section{International Journal of Business Management and Economic Review}

Vol. 3, No. 01; 2020

ISSN: 2581-4664

income. To measure growth, the indicator frequently used in research is the gross domestic product. Growth is a term generally used by some economists to describe an increase in production over the long run. Economists distinguish two types of growth. Extensive growth refers to the rise in the quantities of factors of production. This growth allows the creation of new jobs. Intensive growth is the increase in output through productivity gains(Curea \& Ciora, 2013). The definition of growth and its measurement are very original concepts, which can result from the beginning of industrialization. According to economists such as, economic growth is driven entirely by natural quantity of non-renewable resources available, demographics (population growth and changes in activity rates) and by uncontrollable events(Robinson \& Thierfelder, 2002).

Great revolution came from Robert Solow in 1956, which takes into account the residual factor (the technical progress considered as exogenous) in the theory of growth. After Solow's publications, several studies have carried out, notably those of Arrow (1962) on learning by doing(M.R, 2000), on optimal technical progress on human capital. All of this work has shed much light on the process of growth. These theories (the technological progress considered as exogenous) belong to the theorists of the exogenous growth. However, from the beginning of the reflections on economic growth, other explanations have been proposed: these are the theories of endogenous growth because they place the origin of growth in the very functioning of the financial system. The new methods of endogenous growth will gain renewed interest from the 1980s with the work of (Moore \& Christin, 2013), All these different models have emphasized the fundamental role of the accumulation and diffusion of technology in economic growth.

\section{Impact of Foreign Direct Investment (FDI) on Economic Growth}

The literature on the impact of FDI on growth especially that of developing countries, is particularly abundant. Currently, economists tend to recognize a generally positive effect of FDI on growth in developing countries, but with often significant nuances. The results of research on the impact of FDI on growth are still unconcluded as to the expected or realized effects. The analyzes carry out at the micro- and macroeconomic levels show that these effects can be at times decisive, neutral or even harmful. Finds that there is little evidence of a positive effect of foreign investment on growth for recipient countries. Likewise(African Development Bank Group, 2019), studying the potential positive effects of firms with a majority of foreign capital on local firms, conclude that there is usually a negative impact. As shown the need for prerequisites for assessing the link between foreign investment and growth. It establishes that this link is unstable, positive or negative, depending on the state of the environment, favorable or not, in which the investments intervene. At the decision-making level, opportunities for technology transfer, externalities and other benefits for recipient countries have led to the introduction of incentives in different forms to attract foreign investment(Moore \& Christin, 2013). Romer estimates that foreign investment can bring significant benefits in terms of technology transfer and innovation in management, thereby helping to reduce the development gap, precisely in the accumulation of physical and social capital. It is improving human capital, between rich and developing countries. The researches of the links between foreign investment and growth can consider, as indicated above at the microeconomic and macroeconomic level. At the microeconomic level, studies have sought to assess the impact of FDI on different sectors (primary, secondary and tertiary) and the horizontal or vertical distribution of spillovers(MAS \& 


\section{International Journal of Business Management and Economic Review}

Vol. 3, No. 01; 2020

ISSN: 2581-4664

FSNWG, 2013). Most of these sectoral studies make a positive contribution to investment in the secondary and tertiary sectors and a neutral or even negative impact on the primary sector, particularly in agriculture show that technology transfers generated by foreign investment generally go to secondary and tertiary sector firms rather than to the primary sector. Because the primary sector (agricultural) uses much less technology than other areas, particularly in developing countries, while the mining resource industries are technologically poorly connected to other local firms. (pesaran, 2007) points out, the potential for FDI to create technological linkages between domestic firms is essential for the diffusion of innovation. Ndikumana (2008) conducted a study in sub-Saharan African countries on the two- way links between FDI and national investment. Its results suggest that, on the one hand, investments in FDI by many domestic investors and, on the other hand, that countries have an interest in putting in place policies to improve the local investment climate. Also, there are alternatives to natural resources to attract foreign investment in non-resource-rich countries(Curea \& Ciora, 2013). Go in the same direction, arguing that FDI has a positive effect on growth when the country in question is sufficiently rich in per capita income. Also argued that FDI leads to growth, but only in countries where the labor force has reached a certain level of learning. Researched some African countries such as South Africa, Nigeria, Egypt, Kenya, and the Central African Republic. The study focused on the effect of foreign direct investment on economic growth from 1980 to 2014(Zhang, 2001b). They used ordinary and dynamic least-squares panel estimation techniques. The strange fact of the research was the inability of gross capital formation, human capital, and global technology in the Central African Republic to influence economic growth.

Impact of FDI on the economic growth of African countries is limited or negligible, both for MLS estimates and for dynamic panels. The results also showed that FDI had more affected South Africa's growth than Nigeria, Egypt, Kenya and the Central African Republic. (Robinson \& Thierfelder, 2002)has sought to see whether the quality of institutions in five regions SSA, MENA, Europe, Asia, and America favors the effect of the foreign direct investment on economic growth. Using the GMM system from 1984 to 2013, his findings highlight the role of institutional development in mitigating the ambiguous effects of FDI on GDP growth. It gives importance to the index of institutions for all groups, except for the United States group. Referring to the components of the institutions, we note that beyond the stability of the government and respect for law and order, FDI affects GDP growth(Graf Von Der Schulenburg et al., 2008) studies the effects of direct investment on growth in the 12 Latin American countries. Used panel data from 1950 to 1985, his results reveal a significant and positive relationship between foreign direct investment and economic growth. Also researched the relationship between foreign direct investment and Kazakhstan's economic growth as a factor in the diversification of the economy. Used data from 1994 to 2013, the results showed that there was a significant relationship between GDP, FDI, and gross capital formation. But no dependence between the human development index and the GDP. Shed light on the empirical relationship between foreign direct investment and economic growth. A vector error correction method is adopted using annual time series for Ireland from 1976 to 2011. Their result revealed that the existence of a significant relationship between GDP, FDI, net inflows, exports and the development of the financial system in the long and short term. And also that there is a unidirectional causality between GDP and FDI(Curea \& Ciora, 2013), ranging from GDP to FD.) 


\section{International Journal of Business Management and Economic Review}

Vol. 3, No. 01; 2020

ISSN: 2581-4664

The impact of FDI on economic growth in countries like Angola, Nigeria, Egypt, Mali, Botswana, Burkina Faso, South Africa, Côte d'Ivoire, and Tunisia from 1970 to 2003. In its regression, it used GDP as a dependent variable and FDI, gross capital formation and export balance as the independent variable. Its results reveal that the effects of FDI are positive in several countries: Nigeria, Egypt, Mali, Botswana, and Burkina Faso. Still, it is only in Angola that this effect is positive and significant. However, several other countries such as Côte d'Ivoire, South Africa, and Tunisia show the negative impact of FDI on economic growth (pesaran, 2007)also studied the impact of foreign direct investment on Benin's economic growth between 1970 and 2002. The method used is the simultaneous equation system and tested by the two-step method. The result shows that FDI has a positive and significant effect on the growth rate and is more efficient than national investment. Human capital and the degree of openness of the economy do not play a substantial role as a catalyst for the country's growth. Their interaction with FDI has a positive effect but has no significant effect on the growth rate. Cristina Jude (2017) investigated the link between FDI and domestic investment in the 10 Central and Eastern European countries over the period 1995-2015. The result shows that FDI leads to a destructive creation phenomenon, with a knock-on effect. Short-Term foreclosure on domestic investment(Davis, 2011), followed by long-term crowding. New FDI enhances the long-term complementarity of domestic investments, while mergers and acquisitions have no significant effect on domestic investment. Economic development appears to ease foreclosure pressures and even foster the concentration of mergers and acquisitions.

According to Brewer (1991), there is an adverse effect of FDI on economic growth. Indeed, this negative effect can explain it by the result of the domination exercised by foreign companies on local businesses which discourage them from developing their research and development activities.

\section{CHANNELS HOW FDI AFFECTS GROWTH}

It remains challenging to measure their impact of FDI on the host country, especially by reasoning on global economic notions such as growth; so many factors can explain growth, often correlated between them. For example, good economic governance, infrastructure development, an increase in the labor force, adequate training of the workforce, productivity gains, a particular trade openness, injection of foreign capital all seem to contribute to an acceleration of GDP(Graf Von Der Schulenburg et al., 2008). But at the same time, adverse effects cannot be ruled out (trade openness as a foreign investment can have a crowding-out impact on domestic businesses, infrastructure can be disproportionate and cost more than they bring. It seems more complex evaluation system in combination of factors in the generation of foreign direct investment and their effects to give a good result.

\subsection{Effect on the accumulation of capital}

FDI reinforces the stock of money that materializes with new capital goods and obliges companies to make sustainable commitments. Productive assets included in FDI have immediate repercussions on the local economy through competition, imitation, labor turnover or the creation of vertical. It thus favors the accumulation of capital in the recipient country. For evidence, reach at the conclusion with a sample, as heterogeneous, of 69 developing countries over the period 1970-1989. But for them, FDI affects domestic investment in a ratio of more than one: an 


\section{International Journal of Business Management and Economic Review}

Vol. 3, No. 01; 2020

ISSN: 2581-4664

increase of one dollar in the net inflow of FDI is associated with an increase of more than one dollar in the total investment of the host country. The value would be between 1.5 and 2.3. FDI seems to stimulate investment in activities complementary to those undertaken by multinationals (crowding-in effect). However, this study has the defect of not having differentiated the results according to the regions because the flows towards them are not identical, areas which at least do not have all the same characteristics. It would, therefore, be adequate to extend this analysis and to estimate the effects of capital flows by region, since it is likely that the results for sub-Saharan

Africa, particularly for West Africa, would have been close to those obtained for the group of emerging countries(Council \& Kong, 2015). According to these authors, FDI inflows can help reduce the financing constraints of domestic firms. One of the main obstacles to investment in developing countries is the unavailability of financial resources and lack of access to these resources. From this perspective, FDI can reduce these constraints by providing the necessary financial support in the capital for developing countries. Besides, insufficient development of the domestic banking sector can make it difficult for local businesses to access external financial resources. In this case, it can slow down investment and prevent local companies from exploiting the opportunities created by the presence of foreign firms in the country. (Capco, 2016)made a study on the impact of FDI on the financial markets of Côte d'Ivoire between 1974 and 1987. They show that the MNCs, thanks to the superiority of their guarantees and their profitability, benefit from more convenient access to local banks to the detriment of local businesses. (Schulenburg et al., 2008)research the impact of foreign direct investment on Nigeria's economic growth. Their objective was to determine the nature, trend and sectoral flows of foreign direct investment relative to economic growth in Nigeria and to identify the effect of FDI on selected macroeconomic indicators from 1970 to 2010. Their results demonstrated that there is a long-term relationship between dependent and independent variables(Council \& Kong, 2015). These results correspond to the prior expectations of the economy. And also show that gross capital formation has a positive and significant correlation with economic growth. In conclusion, they recommended that capital formation promote economic growth through the introduction of savings accumulation visas, an increase in gross domestic investment. And also that constructive attention must be given to the provision of the necessary services(Stephen, n.d.). Estimate the impact of foreign direct investment on capital accumulation and output growth and total factor productivity (TFP) in the recipient economy. Time series and panel data provided for a sample of OECD and non-OECD countries for the period 1970-90. While foreign direct investment expected to stimulate long-term growth of the recipient economy through technological upgrading and knowledge spillovers, it is shown that the extent to which FDI encourages growth depends on the degree of complementarity and substitution between FDI and domestic investment. (Bank, 2012)find that countries benefiting from the positive effect of FDI on growth are those with a moderately developed financial market For the economic literature, technology transfer may be the primary mechanism by which the presence of foreign firms can have positive externalities in the developing host economy(Bur fisher,

M.E., Robinson, S. and Thierfelder, 2001). Indeed, multinational enterprises are the primary source of research and development ( $R \& D$ ) activities in the developed world, and their level of technology is generally higher than that of developing countries so that they can generate very 


\section{International Journal of Business Management and Economic Review}

Vol. 3, No. 01; 2020

ISSN: 2581-4664

significant technological spin-offs. Nevertheless, the role played by multinational enterprises in facilitating these spillovers varies according to economic context and sectors. Technology transfer and diffusion achieved through four interdependent mechanisms: vertical linkages with suppliers or acquirers in host countries; horizontal links with competing or complementary companies of the same branch; migrations of qualified personnel. The availability of modern technologies is perhaps the main reason why countries want to attract foreign investment. Thanks to these, they can obtain technologies that they cannot manufacture themselves (Diao, X., Roe, 2001). Since the expected effect of FDI on growth based on the absolute necessity of transferring technologies to the host country, these open their doors to multinationals, which recognized as the primary vectors of the international diffusion of technology. They are an essential part of the world's research and development and generally control the most advanced technologies. And developing countries characterized by the weakness of their R \& D resources then depend on foreign multinationals to access modern technology. It is, in fact, thanks to technical progress that FDI stimulates growth, two main channels through which FDI may lead to increase. First, FDI can promote the adoption of new technology in the production process through capital spillovers. Second, FDI may stimulate knowledge transfers, both in terms of labor training and skill acquisition and also by introducing alternative management practices and better organizational arrangement, FDI makes it possible to increase the rate of technical progress in the host country through the contagion effect of more advanced technologies, management practices, used by foreign firms. The presence of multinational companies creates technological spinnakers in the medium and long term. There are spillovers, according to when MNEs cannot obtain total rent or internalize the beneficial effects of their presence in the host country.

(Costa, 2006) has made an analysis showing that FDI is attracted more by countries that have profitability, such as countries with a skilled workforce and an advanced and organized level of innovation. In contrast, FDI drives the accumulation of human capital in these countries and thus increases the rate of economic growth in the long term. In the two-country dynamic model, he showed the importance of human capital accumulation as a factor in attracting capital(XU, 2000). And the contribution of high-technology FDI inflows to the growth of macroeconomic aggregates and the welfare of the host country. And he concludes that the level of growth attracts FDI, which at the same time affects growth. (Council \& Kong, 2015) investigates the nature and importance of FDI productivity externalities on the productivity of host-country firms, in terms of intra- industry and cross-sectoral benefits, using Zambian data. Its results have shown little evidence to support the interests of intra-industry productivity of FDI, and cross-sectoral knowledge spillovers through linkages. He concluded that the net impact of FDI depends on the interaction between intra-industry and inter-industry productivity effects.

\section{COMMERCIAL OPENNESS}

The opening of a country is not limited to its international exchanges. Characterized by its ability to host foreign multinational firms by granting benefits, including tax and administrative Firms can improve the overall efficiency of an economy through the availability of technological and organizational knowledge transferable to the rest of the economy. Thus, to take into account all the catalysts, some authors add economic openness(De Melo, J. and Robinson, 1992). Economic growth can be driven by investment through trade openness have made a study of the impact of FDI on investments by region, South Korea and Latin America. 


\section{International Journal of Business Management and Economic Review}

Vol. 3, No. 01; 2020

ISSN: 2581-4664

Results from two regions showed the effect of overpopulation in South Korea and the crowding out of Latin American countries. Because the first country has very selectively opened its market to foreign investors, like most Asian countries, while the latter pursued a policy of total openness. They try to show that countries that have managed to maximize the potential of FDI, such as in Asia, are among the countries that have adopted the most restrictive policies in this area, thus preserving their domestic firms from foreign competition(Stephen, n.d.). In contrast, the example of Latin America shows that the total liberalization of the FDI regime has been disappointing. does a study on the openness of the economy to international trade can affect the growth of real GDP per capita, or growth it can affect the opening of trade in the member countries of WAEMU. It uses three measures of trade openness, and causality tests applied by Johansen's co-integration and error correction method (Diao, X., Roe, 2001). The results showed that the sense of causality between trade openness and economic growth in WAEMU member states is sensitive to the choice of indicator used. For the commercial opening. The causality tests show a different pattern of causality among the eight-member countries. These results correspond to the point of view that the openness of the economy to international trade promotes economic growth. In contrast, growth leads to an associated increase in openness to trade. It suggests that the promotion of exports and imports of goods and capital, as well as the improvement of infrastructure, human capital and institutional quality, help to overcome the weaknesses of the regional financial system, to improve the dynamics of growth (Arcand, 2013) trade and contribute to the economic growth of WAEMU member countries conducted a study on the impact of foreign direct investment on economic growth from 1981 to 2008 they used three- panel estimation models, called combined models, fixed-effects models and Random Effect Models all variables can contribute to economic growth as they increase (B.Hefeker, 2007), with FDI becoming the most effective variable for promoting economic growth, followed by openness and gross fixed capital formation. Otherwise, the ordinary least squares study results also verify that all stationary variables are significant at 5\%, which show that only gross fixed capital formation is important for growth and contributes to growth the positive effect on the GDP of each ASEAN country, however, and the result of the MCO estimate for Indonesia shows that the other variable shows significant growth, namely openness; it gives the negative effect of GDP. (Graf Von Der Schulenburg et al., 2008)made a study of foreign direct investment, trade, and economic growth in India from 1970 to 2007. Their integration result showed that there is a long-run equilibrium relationship. But the result of Granger's causality test showed that there is a cause- and-effect relationship between the variables used. Economic growth, trade, and FDI seem to be mutually reinforcing under the open door policy. (Aggawal, G, 2006)examines the link between economic growth and foreign direct investment for Portugal. Used a data panel approach, the results show that foreign direct investment and bilateral trade promote economic growth. Growth negatively correlated with inflation and the initial level of GDP per capita. In the same spirit. (Adams, 2009) use average annual cross-sectional data over the period 1970-1985 for 46 developing countries and emphasize that trade openness is crucial for the potential impact of FDI on growth. Their analysis indicates that FDI is more productive in countries that have applied export promotion policy rather than import substitution policy. (Sahn, D., P. Dorosh, 2000)confirms that the impact of FDI is significantly positive for open countries and significantly negative for those that are not. (Zhang, 2001b) showed that FDI had a positive impact on the growth of transition countries in Central and Eastern Europe over the period 1990- 


\section{International Journal of Business Management and Economic Review}

Vol. 3, No. 01; 2020

ISSN: 2581-4664

1998. They point out that this effect is partly because these countries were at the beginning of the process of total privatization (the component of trade liberalization) at a time when FDI flows reached their peak at the global level. Similarly, examined whether trade liberalization could play an important role in explaining the short- and long-term dynamics of the causal link between FDI and growth.

They use a panel of 23 countries with a study period from 1978 to 1996(Bank, 2012). Their counteraction analysis suggests that there is a long-term relationship between FDI and the growth of all countries. But in the short term, differences are depending on the degree of openness of countries. In the long term, only open countries benefit from the impact of FDI on growth. (B.Hefeker, 2007)analyzes the explanatory factors of foreign direct investment in WAEMU and the possible economic policy measures that EU countries might consider to increase their attractiveness to international investors. According to an econometric study on panel data covering the years 1980 to 2002, the study shows that some traditional factors, such as the openness of the economy to international trade, the rate of investment, especially the rate of public investment, human capital, are crucial. (Robinson \& Thierfelder, 2002)in the analysis of FDI flows to the WAEMU zone. These results suggest that states could pursue policies aimed at increasing the rate of public investment and continuing education efforts. These results also encourage the strengthening of the economic integration introduced with the creation of the Economic Union in 1994 and the pursuit of reforms related to openness to international trade. These economic policy measures contribute to improving the business climate and should not only increase the flow of FDI into the Area, but also the quality of these investments(Curea \& Ciora, 2013).

\subsection{Effect on infrastructure}

In the literature, support presented as intermediate goods that facilitate trade and improve the productivity of other inputs in the production. Infrastructure can define as a result of the work of, as goods and services that support economic activity(African Development Bank Group, 2019). In addition to physical infrastructure such as electricity, transport, and communications, whose characteristic is to participate in the productive process, proposes a broader definition that includes social infrastructure including education and health whose function is to maintain and develop human capital. Support is more understood as a factor in improving product performance and private sector investment. Support is at the heart of the concerns of developing countries(Council \& Kong, 2015). Quality infrastructure is a prerequisite and essential to attracting and successful foreign investors. Poor support or absence of public goods increase costs for businesses. FDI provides not only substantial funds but also modern technologies, advanced skills, and knowledge, which also makes it easy to carry out the project at low cost and with minimum deadlines. FDI is considered the most important means of transferring modern technologies, funds and innovative ideas from one country to another for the development of the host country(Economics, 1997). FDI helps to improve the situation of various infrastructure sectors such as transport, electricity, communications, and tourism and, in general, contributes to the smooth running of production activities. And water and sanitation that facilitate community development. On the other hand, good infrastructure attracts more FDI to developing countries. In addition to the excellent size of the infrastructure market, the banking system, the regulation 


\section{International Journal of Business Management and Economic Review}

Vol. 3, No. 01; 2020

ISSN: 2581-4664

of financial markets, political and economic stability, and stability, fiscal incentives are other vital factors affecting FDI inflows and shave a positive impact on the economic growth. (Blomström, M., Fors, G., \& Lipsey, n.d.) Analyzes the effects of infrastructure on FDI in developing countries. Electricity consumption and the number of fixed telephone lines used as proxy variables for infrastructure and GDP, population, inflation, and openness as control variables. Based on a panel of 55 countries over the period 1990-2014, the results show that the availability of electricity infrastructure contributes to the attractiveness of FDI in developing countries. However, the availability of the landline does not attract foreign investors, both in developing.

\section{METHODOLOGY}

To better understand the effects of foreign direct investment on growth, several Econometric methods have been used by authors in their research. But we will do a brief critical review of these different methods before proposing the approach that seems best for us in our work(Robinson \& Thierfelder, 2002). A short discussion of econometric methods. In the case of country-specific studies, the use of time series is one of the appropriate techniques. The main argument in favour of these has been that panel studies implicitly imply or imply a typical economic structure and a similar production technology between different countries(Barrios, S., Gorg, H., \& Strobl, 2005). At the same time, the time series makes it possible to highlight the specificities of each country studied. Indeed, a country's economic growth is not only influenced by FDI and other factors of production. It can also be affected by many domestic policies such as education, fiscal and external policies that channeled through which the benefits of Foreign direct investment can maximize. The other method is the use of the simultaneous equation linear system. Some have used this type of model to observe the impact of FDI on the economy. These models have the main advantage of taking into account the endogenous nature of growth, the two meaning of causality into the system.

\subsection{Specification of the analysis model}

In this paper, we will study and evaluate the effects of FDI on the economic growth of WAEMU 8 member states, from 1994 to 2015 empirically. We will use the Random fact and fixed effect for our empirical estimates. Several studies have given different specifications regarding the relationship between FDI and economic growth. Understanding the fundamental relationship between FDI and output growth, a simple production function was used but added several light difference variables (pesaran, 2007). The starting point of the model formulation is:

$Y=f(A, F D I, K)$

Where $\mathrm{Y}$ is output; Gross Domestic Product (GDP), and $\mathrm{K}$ is capital stock. The variable A captures the total factor productivity of growth of the production.

$Y=f(F D I, G o v c o n, G F C F$, Infla,Lab,Energy,Trad) The model described as follows:

$G D P=\beta_{0}+\beta_{1} F D I+\beta_{2}$ GOVCON $+\beta_{3} G F C F+\beta_{4} I n f L a+\beta_{5} L a b+\beta_{6}$ Energy $+\beta_{7}$

$\operatorname{Trad}+\epsilon(1)$

Energy $+\beta_{7}$

$G D P=\beta 0+\beta 1 F D I+r D * P * F D I+\beta_{2}$ GOVCON $+\beta_{3} G F C F+\beta_{4} I n f L a+\beta_{5} L a b+\beta_{6}$

$\operatorname{Trad}+\epsilon(2)$ 


\section{International Journal of Business Management and Economic Review}

Vol. 3, No. 01; 2020

ISSN: 2581-4664

Where P is a dummy variable of recent years.
GDP $=\beta 0+\beta 1 F D I+r D * L$ and $* F D I+\beta_{2}$ GOVCON $+\beta_{3} G F C F+\beta_{4} I n f L a+\beta_{5} L a b+\beta_{6}$
Energy
$\quad+\beta_{7}$ Trad $+\epsilon(3)$
GDP $=\beta 0+\beta 1 F D I+r D * B i g * F D I+\beta_{2}$ GOVCON $+\beta_{3} G F C F+\beta_{4} I n f L a+\beta_{5} L a b+\beta_{6}$ Energy +

$\beta_{7} \operatorname{Trad}+\epsilon(4)$

Where Big is a dummy of big countries, by GDP size countries $\mathrm{Big}=1$, or, Big=0.

$G D P=\beta 0+\beta 1 F D I+r D * H i g h * F D I+\beta_{2}$ GOVCON $+\beta_{3} G F C F+\beta_{4} I n f L a+\beta_{5} L a b+\beta_{6}$ Energy

$+\beta_{7} \operatorname{Trad}+\epsilon(5)$

Where high is the dummy of the top countries income

GDP (current), The GDP here is considered the aggregate gross value added by all resident producers in the economy, adding taxes on products, subsidies, and not included in the amount of production.

Foreign Direct Investment (FDI) is a cross-border investment by an investor to establish a sustainable financial interest in a sector or business and to influence the operation of the company. The net FDI used in this study corresponds to FDI inflows in millions of United States dollars. Similarly, foreign direct investment should generally have a positive effect on real output as it considers a cross-border investment.(Curea \& Ciora, 2013)Gross fixed capital formation includes land improvements, purchases of factories, machinery and equipment; and the construction of roads, railways, schools, offices, hospitals Etc. According to, this is "the increase in the real capital stock of a country". Theoretically, capital (K) measured by gross domestic capital formation as a percentage of gross domestic product expected to have a positive impact on the GDP growth rate. Infla (consumer prices), inflation, reflects the annual percentage change in the average consumer's acquisition cost of a fixed basket of goods and services that can set or modified at fixed intervals, for example, once a year. Inflation should reflect general macroeconomic instability and should, therefore, be negatively related to growth.(Robinson \& Thierfelder, 2002) Trade (import and export), trade variable is the sum of exports and imports of goods and services. Trade liberalization (trade openness) is often assumed to be the way to growth through various means, such as access to advanced technologies from abroad, catch-up opportunities, greater access to a variety of access to more efficient markets through increased specialization. Thus, theoretically, the effect of the openness of the economy on GDP growth is positive. General government consumption, General government final consumption expenditure includes all current spending of the general government on the acquisition of goods and services (including compensation of employees). Also includes spending on national Defense and security but excludes government military expenditures that are part of the government's capital formation. Public expenditure should stimulate the economy and have a positive effect on real output. The total labor force (Lab), includes those who are currently employed and looking for work(Graf Von Der Schulenburg et al., 2008). However, not everyone who works is involved. Unpaid workers, family workers, and students often omitted, and some countries do not count members of the armed forces. The size of the labor force tends to vary throughout the year, as does the entry and exit of seasonal workers. The variable energy is the ratio between energy 


\section{International Journal of Business Management and Economic Review}

Vol. 3, No. 01; 2020

ISSN: 2581-4664

supply and gross domestic product measured at purchasing power parity. Energy intensity is an indication of the amount of energy used to produce an economic unit of production(Curea \& Ciora, 2013). A lower ratio indicates that less energy used to create a group of output.

\section{Data source:}

At the international level, the statistical data are relatively homogeneous. In West Africa, for example, FDI statistics come mainly from the Central Bank of West African States (BCEAO). They are then taken up by the Bank of France (reports on the Franc Zone), the IMF (which also sometimes provides its estimates for recent statistics in the "country reports") and the United Nations Conference on Trade and Development. Online statistics or World Investment Reports). The latter is the reference source in this area (Sahn, D., P. Dorosh, 2000). Generally, UNCTAD collects FDI statistics from central banks, statistical offices, and national authorities and then compiles them with the IMF, the World Bank, and the OECD. For WAEMU, the BCEAO seems to provide the complete statistics. It obtains them from investigations of its agents with the companies concerned. The National Statistical and Information Departments (DNSI) also collect statistics on large enterprises that could provide information on FDI flows.

Favor the homogeneity of the data, and two sources have exploited. These data cover the period 1994-2015, selected for the analysis. The reasons for this choice are the implementation during this period of several economic and financial policy measures in the Union, in particular, the

Convergence, Stability and Solidarity Pact, the Customs Union, the standard external tariff, to attract FDI to the union(Curea \& Ciora, 2013).

\section{Hypothesis}

Based on economic theories, the literature on FDI and observations, we formulate the following suggestions: The assumption is that FDI in WAEMU countries and possible impacts on economic growth. We will put some explanations in place to achieve our goals, which we have set.

$\mathrm{H}_{1}: d G D P d F D I>0$, this means that foreign direct investment over the entire period of study has a positive effect on WAEMU's economic growth; this assumes that FDI inflows should have a positive impact on GDP. That said, if FDI increases, it will contribute to economic growth.

$\mathrm{H}_{1.1}: d G D P d F D I<0$, this means that foreign direct investment over the entire period of study does not have a positive effect on WAEMU's economic growth; this implies that FDI inflows are insufficient or insignificant to have a positive impact on GDP.

$\mathrm{H}_{2}: d G D P d P F D I>0$, this means foreign direct investment in recent years has had a positive effect on the economic growth of the WAEMU countries. And we assume that any increase in foreign direct investment expected to increase growth.

$\mathrm{H}_{3}$ : $d G D P d l a n d F D I>0$, this means that foreign direct investments of WAEMU landlocked countries have a positive effect on growth. We assume that any increase in foreign direct investment expected to increase growth.

$\mathrm{H}_{3.1}$ : $d G D P$ dlandFDI $<0$, his means that foreign direct investment from WAEMU landlocked countries does not have a positive effect on growth. Implies that foreign direct investment inflows are either insufficient or insignificant to have a positive impact on GDP. 
Vol. 3, No. 01; 2020

ISSN: 2581-4664

$\mathrm{H}_{4}$ : dGDPbigFDI $>0$ this means the foreign direct investment of the four largest WAEMU countries in terms of GDP has a positive effect on growth. We assume that any increase in foreign direct investment expected to increase growth.

$\mathrm{H}_{5}$ : dGDPhighFDI $>0$ this means the foreign direct investment of the four largest WAEMU countries in terms of GDP per capita has a positive effect on growth. We assume that any increase in foreign direct investment expected to increase growth.

\section{Empirical Results and interpretation}

This table describes statistically all the variables used in this study. We used Panel data for this analysis of WAEMU different countries, the effect of FDI on economic growth from 1994 to 2015

\section{Table 1 Descriptive Statistic}

\begin{tabular}{cccccc}
\hline Variables & Obs & Mean & Stv. Dev & Min & max \\
\hline FDI & 176 & $1.59 \mathrm{e}+08$ & $2.03 \mathrm{e}+08$ & $-4.10 \mathrm{e}+07$ & $1.10 \mathrm{e}+09$ \\
GDP & 176 & $6.61 \mathrm{e}+09$ & $6.51 \mathrm{e}+09$ & $2.10 \mathrm{e}+08$ & $3.50 \mathrm{e}+10$ \\
Govcon & 176 & $9.86 \mathrm{e}+08$ & $9.27 \mathrm{e}+08$ & $1.60 \mathrm{e}+07$ & $4.40 \mathrm{e}+09$ \\
GFCF & 176 & $1.27 \mathrm{e}+09$ & $1.21 \mathrm{e}+09$ & $2.30 \mathrm{e}+07$ & $6.70 \mathrm{e}+09$ \\
Infla & 176 & 5.366648 & 8.721386 & -9.82383 & 46.3861 \\
Lab & 176 & 3882500 & 1944061 & 440417 & 7800000 \\
Energy & 176 & 8.273903 & 3.627919 & 1.91032 & 17.265 \\
Trad & 176 & $4.56 \mathrm{e}+09$ & $5.32 \mathrm{e}+09$ & $1.04 \mathrm{e}+08$ & $2.51 \mathrm{e}+10$ \\
& & & & & \\
\hline
\end{tabular}

Table 1: summarizes the statistics of all the variables we used in our study. The data used are from 1994 to 2015, with one observation per country. GDP has a minimum value of $2.10 \mathrm{e}+08$ and a maximum value of $3.50 \mathrm{e}+10$, its average is $6.61 \mathrm{e}+09$, and the standard deviation is $6.51 \mathrm{e}+09$, the most important is that its dispersion is above average. The average FDI for the sample is $1.59 \mathrm{e}+08$ per year. With a standard deviation of $2.03 \mathrm{e}+08$, it increases gradually, ranging from $-4.10 \mathrm{e}+07$ to $1.10 \mathrm{e}+09$ in the sample. The public consumption has a minimum value of $1.60 \mathrm{e}+07$ and a maximum value of $4.40 \mathrm{e}+09$. It has an average of $9.86 \mathrm{e}+08$, and the standard deviation is $9.27 \mathrm{e}+08$, which is above average, so it has a significant dispersion. Public consumption usually measured by the ratio of general use to GDP. It should be directly related to economic growth, as increased state spending expected to increase social capital, which in turn encourages production and growth. Inflation has the lowest value of -9.82383 and the highest value of 46.3861 , the average is 5.366648, and the standard deviation is 8.721386 , which is high, which means that it has a dispersion above average. Inflation, as expected, harms the attractiveness of FDI but is statistically less active. As far as the rise is concerned, it can have 


\section{International Journal of Business Management and Economic Review}

Vol. 3, No. 01; 2020

ISSN: 2581-4664

a dual content of information - macroeconomic instability and vigorous economic activity, as in the case of economic overheating. Most African countries have not achieved sustainable economic growth, let alone overheating. It can, therefore, said that the informational content of inflation tends more to financial instability. The gross fixed capital formation has a minimum value of $2.30 \mathrm{e}+07$, and the maximum amount is $6.70 \mathrm{e}+09$, its average of $1.27 \mathrm{e}+09$ and the standard deviation of $1.21 \mathrm{e}+09$, which its dispersion is above average. The total workforce has a minimum value of 440417 and a maximum value of 7800000 . Its average is 3882500 ; the standard deviation is 1944061 , which means that it has a lower than average dispersion. The quality of the workforce is one of the essential factors, with a $99 \%$ confidence interval, which determines the inflow of FDI. Developing countries have considerable room for maneuver to determine the amounts to invest in education and training. The more an African country spends on human capital; we find that more FDI goes to this country. The trade has a minimum value of $1.04 \mathrm{e}+08$ while the maximum amount is $2.51 \mathrm{e}+10$, its average is $4.56 \mathrm{e}+09$ and the standard deviation of 5.32e +09 , and its dispersion compared to the average is smaller. According to trade in goods and services, we can say that the expectations of our results should be a positive sign of economic growth. Finally, the energy has a minimum value of 1.91032 and a maximum value of 17.265 , its average is 8.273903 , and the standard deviation is 3.627919 , which means that its dispersion is higher than that of the norm. After the results of the descriptive statistics, we will follow our regressions. Where GDP is the dependent variable, and the others are independents.

\section{The results of Fixed and Random effect regression}

\section{Table 2: Fixed and Random Effect}

\begin{tabular}{lcc}
\hline Variable & Fixed & Random \\
\hline fdi & $-2.2438762^{* * *}$ & $-1.7461175^{* * *}$ \\
govcon & $2.129298^{* * *}$ & $1.7181145^{* * *}$ \\
gfcf & $1.4756226^{* * *}$ & $1.0030865^{* * *}$ \\
infla & -2765426.1 & 5997374 \\
lab & 26.141767 & \\
& & 75.400462 \\
trad & $.51075635^{* * *}$ & $.74637414^{* * *}$ \\
energy & -207197.99 & $61466448^{* * *}$ \\
cons & $5.898 \mathrm{e}+08$ & $7.067 \mathrm{e}+08^{* *}$ \\
\hline $\mathrm{N}$ & 175 & 175 \\
r2_a & .98563721 & .97249869 \\
Group & 8 & 8 \\
Obs & 175 & 175 \\
$P$ (F) & 0.000 & 0.000 \\
$R^{2}$ & 0.9747 & 0.9747 \\
& & \\
\hline
\end{tabular}

legend: $* \mathrm{p}<.1 ; * * \mathrm{p}<.05 ; * * * \mathrm{p}<.01$ 


\section{International Journal of Business Management and Economic Review}

Vol. 3, No. 01; 2020

ISSN: 2581-4664

According to the results of the random effect, the coefficient of estimation R2 has a high value of 0.9679, which indicates that there is a strong relationship between the GDP and the other variables. The coefficient of FDI on the whole charm harms the economic growth of the WAEMU countries. Variables such as GFCF (0.000), Govcon (0.0000) and trad (0.000) are all significantly positive for union economic growth, others such as inflation (0.148), labor (0.957) and $\mathrm{Lab}(0.320)$. Since the p-value is greater than 5\%, these variables are not significant (GBCF, Govcon, and Trad) have a positive impact on economic growth: if they increase by one unit, the GDP will also increase by one unit.

According to our fixed effect result, too, the estimated value of R2 is 0.9747 , which means that there is a strong relationship between the dependent variable and the independent variables. The p-value of the FDI is (0.002) significant, but the coefficient is negative. Variables such as GFCF (0.000), Govcon (0.000) and Trad (0.000) all have a positive impact on economic growth. The variables: energy (0.106), Lab (0.276), inflation (0.753), is not significant, their pvalue is higher than 5\%; these variables contribute little to the economic growth of WAEMU.

These negative FDI results are likely due to the non-diversification of FDI between development sectors. Most of the FDI in WAEMU countries directly oriented in the exploitation of natural resources, which does not favour the transfer of technology and the profit of foreign investors repatriated.

\section{Hausman's Test}

\begin{tabular}{llllc}
\multicolumn{6}{c}{ Coefficients } & & \\
\hline & (b) & (B) & (b-B) & $\begin{array}{c}\text { sqrt(diag(V_b-V_B })) \\
\text { Difference }\end{array}$ \\
& random & fixed & .4977587 & .1447725 \\
fdi & -1.746117 & -2.243876 & -.4111835 & \\
govcon & 1.718114 & 2.129298 & -.4725361 & .0145147 \\
gfcf & 1.003087 & 1.475623 & 8762800 & 3476537 \\
infla & 5997374 & 2765426 & 49.25869 & \\
lab & 75.40046 & 26.14177 & .2356178 & \\
trad & .7463741 & .5107563 & $-6.13 \mathrm{e}+07$ & \\
energy & $-6.15 \mathrm{e}+07$ & -207198 & & \\
\hline
\end{tabular}

$$
\begin{gathered}
\operatorname{chi2}(2)=(b-B){ }^{\prime}\left[\left(V_{-} b-V_{-} B\right)^{\wedge}(-1)\right](b-B) \\
=\quad 5.93
\end{gathered}
$$

Prob $>$ chi $2=0.0516$

(V_b-V_B is not positive definite) 
International Journal of Business Management and Economic Review

Vol. 3, No. 01; 2020

ISSN: 2581-4664

Test of Robustness with 2SLS, LLML and GMM

Instrumental variables (2SLS) Regression

\begin{tabular}{lclll}
\hline gdp & Coef. & Std. Err. & $z$ & $P>|z|$ \\
\hline fdi & -1.824763 & .4521115 & -4.04 & 0.000 \\
gfcf & 1.033172 & .1307874 & 7.90 & 0.000 \\
govcon & 1.838014 & .2604825 & 7.06 & 0.000 \\
infla & 0 (omitted) & & & \\
lab & 125.965 & 32.53476 & 3.87 & 0.000 \\
trad & .7221191 & .0299785 & 24.09 & 0.000 \\
energy & 0 (omitted) & & & \\
cons & 0 (omitted) & & & \\
\hline Number of obs & & 175 & \\
Wald chi2(7) & & 24221.94 & & \\
Prob $>$ chi2 & & 0.0000 & & \\
R-squared & & 0.9854 & & \\
Root MSE & & $7.9 e+08$ & & \\
\hline
\end{tabular}

Instrumental variables (LIML) regression

\begin{tabular}{lcccc}
\hline GDP & Coef. & Std. Err. & $\mathrm{z}$ & $\mathrm{P}>|\mathrm{z}|$ \\
\hline fdi & 1.824763 & .4521115 & -4.04 & -4.04 \\
gfcf & 1.033172 & 1.033172 & 7.90 & 0.000 \\
govcon & 1.838014 & .2604825 & 7.06 & 0.000 \\
infla & (omitted) & & & \\
lab & 125.965 & 32.53476 & 3.87 & 0.000 \\
trad & .7221191 & .0299785 & 24.09 & 0.000 \\
energy & (omitted) & & & \\
cons & (omitted) & & & \\
\hline Number obs & & 175 & & \\
Wald chi2(7) & & 24221.94 & & \\
Prob>chi2 & & 0.0000 & & \\
R-squared & & 0.9854 & & \\
Root MSE & & $7.9 \mathrm{e}+08$ & & \\
\hline
\end{tabular}

\section{CONCLUSION AND RECOMMENDATION}

As part of our study, we empirically analyzed the effect of foreign direct investment on the economic growth of the 8 WAEMU member states between 1994 and 2015. The main objective 


\section{International Journal of Business Management and Economic Review}

Vol. 3, No. 01; 2020

ISSN: 2581-4664

of our paper was to verify the effects of FDI on WAEMU economic growth. Member countries. To do this, we used random effects, fixed effects and GMM methods for our different tests. Allowed us to obtain these different results for the 8 WAEMU countries. These results show us that FDI harms the entire sample. We, therefore, reject our hypothesis that FDI has a positive impact on the whole sample and maintains the alternative hypothesis. However, while we observe other results in recent years, these show us that FDI has had positive effects on the economic growth of the WAEMU countries. In recent years, the relationship between FDI and economic growth in the region is positive. It is through FDI that the holders of modern technology transfer modern technology to countries that do not have it. According to the results of our tests, variables such as gross fixed capital formation, public consumption, and trade opening are all positive and significant. When these variables have a potential impact on economic growth, governments realize that FDI can contribute to economic development and the need to attract it. The global market for this type of investment is highly competitive and developing countries, in particular, want this type of financing to accelerate their development efforts. Economic determinants are nonetheless crucial. As a source of investment capital, FDI stimulates employment. Also, it perceives as a means for WAEMU countries to acquire advanced technologies, new management methods and access to developed countries' markets. Following the many social and economic concerns of WAEMU states, most countries have sought to find a solution to their interests. These concerns included youth unemployment, the high poverty rate, and the crucial lack of technology. WAEMU countries called on the IMF and the World Bank to facilitate the entry of FDI that is likely to play an essential role in economic development. Enterprises have led countries to privatize almost state-owned and introduce some measures that can promote the attraction of foreign direct investment.

\section{RECOMMENDATIONS}

Our study presents a limit due to the nature of the data available. Indeed, the data used did not allow for a sectoral distribution of FDI and to analyze the impact of each sector's FDI on economic growth. We, therefore, wish to undertake studies in this direction, all the more essential for economic policy, as they can help the State in its decision-making to make rational choices for its investments. Improving the macroeconomic framework: It is important to note, however, that a proactive FDI policy alone is not enough to bring about a sustainable acceleration of economic growth. Involves creating stability, first ensuring a stable economic and socio-political environment for foreign investors; increase and improve the quality of the physical infrastructure. Political stability, although we have not been able to measure the relative importance of political instability to attract FDI, this factor plays a no less important role. The weak socio-political climate is detrimental to the image of the region among investors. Improving this image requires efforts at the country level as well as at the regional level. At the national level, promoting good governance, democracy, justice, transparency and respect for human rights will prevent internal conflicts. At the local level, efforts by the Economic Community of West African States (ECOWAS) to maintain peace in the region must continue. The same is true for the ECOWAS moratorium on the import, export, and movement of arms. Other variables such as gross fixed capital formation, general government consumption, and open trade all contribute positively to the economic growth of the union. The results of Labor and Energy are not significant to the growth of the association. To do this, it appears necessary to 


\section{International Journal of Business Management and Economic Review}

Vol. 3, No. 01; 2020

ISSN: 2581-4664

implement measures to train a workforce with the technical and professional qualifications required to respond operationally to the needs of investors. A better match between these needs and the supply provided by the education system achieved. As the country's degree of openness is still low, the government needs to take steps in this direction to increase it while ensuring that the quality of FDI outweighs quantity. Therefore, a question of targeting investments during industrialization with investment policy, it must aim to increase the volume of investments.

\section{REFERENCES}

Adams, S. (2009). Foreign Direct investment, domestic investment, and economic growth in Sub-Saharan Africa. Journal of Policy Modeling, 32, 939-949.

African Development Bank Group. (2019). Macroeconomic developments and prospects Political economy of regional integration. Retrieved from https://www.afdb.org/fileadmin/uploads/afdb/Documents/Publications/2019AEO/REO_201 9__East_Africa_.pdf

Aggawal, G, K. . (2006). Economic analysis of digital economy, 12,15. Arcand, J. . (2013). Transfer de fonds et services financiers sur mobile.

B.Hefeker. (2007). As it is assumed that open economies are better and favorable for export oriented investment. Australian Journal of Agriculture and Resource Economics.

Bajo-Rubio, O. (2000). The Role of the Public Sector. Economics Letters. World Economy, 68, 79-84.

Bank, W. (2012). Migration and Development Briefs Strategic Information and Developments.

Http://Bitcoinist.Net/Mike-Hearn-Has-Left-the-Bitcoin-Building/.

Barrios, S., Gorg, H., \& Strobl, E. (2005). Foreign Direct Investment, Competition and Industrial Development in the Host Country. SSRN Electronic Journal, 12, 247-277.

Berentsen, A. (1998). Monetary Policy Implications of Digital Money. Kyklos, 51, 89118. Blomström, M., Fors, G., \& Lipsey, R. E. (n.d.). Foreign Direct Investment and Employment:

Home Country Experience in the United States and Sweden. Economic Journal, 107. Blundell, W. A. (2014). The Bitcoin Question: Curre OECD Working Papers on Finance,

Insurance and Private Pensions, 37(OECD).

Bur fisher, M.E., Robinson, S. and Thierfelder, K. (2001). The impact of EAC on Uganda Agricultural produce States'. Journal of Economic Perspectives, 15(1), 125-144.

Capco. (2016). The Capco Institute of Financial Transformation.

Costa, M. A. (2006). A produção capitalista do espaço. Trabalho, Educação e Saúde. https://doi.org/10.1590/s1981-77462006000100015

Council, G. C., \& Kong, H. (2015). Revolutionizing the financial markets, 1-2.

Curea, Ş. C., \& Ciora, C. (2013). The impact of human capital on economic growth. Quality - Access to Success, 14(SUPPL. 1), 395-399. https://doi.org/10.1016/s22125671(15)00258-0

Davis, J. (2011). The crypto-currency. New Yorker.

De Melo, J. and Robinson, S. (1992). Productivity and externalities: models of export-led growth. Journal of International Trade and Economic Development, 1, 41-68. 


\section{International Journal of Business Management and Economic Review}

Vol. 3, No. 01; 2020

ISSN: 2581-4664

Diao, X., Roe, T. and S. (2001). Global analysis of WTO reforms in WTO member countries.

Economic Research Service, 25-40.

Economics, C. for I. (1997). An empirical estimate of static welfare losses to Mexico from NAFTA. Panagariya, A.

Gee, J. (1996). a comparison certain aspects of the biology of coffee seeds. African Region Rev.Zool.

Graf Von Der Schulenburg, J. M., Greiner, W., Jost, F., Klusen, N., Kubin, M., Leidl, R., ... Yzer, C. (2008). German recommendations on health economic evaluation: Third and updated version of the Hanover Consensus. Value in Health, 11(4), 539-544. https://doi.org/10.1111/j.1524-4733.2007.00301.x

M.R, A. (2000). "foreign investment in developing countries: Does it Crowd in Domestic Investment?" Discussion Papers, UNICAD, 146.

MAS, \& FSNWG. (2013). East Africa Cross-border Trade Bulletin April 2013. East Africa Cross-Border Trade Bulletin, XX(April), 1-5.

Moore, T., \& Christin, N. (2013). Beware the middleman: Empirical analysis of Bitcoinexchange risk. In Lecture Notes in Computer Science (including subseries Lecture Notes in Artificial Intelligence and Lecture Notes in Bioinformatics). https://doi.org/10.1007/978-3- 64239884-1_3 kyoga.

Ogutu-ohwayo, R. (n.d.). The effects of predation by the nile perch introduced into lake

Institute and Organisation, 335, 18-41.

pesaran, H. (2007). A simple panel unit root test in the presence of cross section dependance.

Journal of Applied Economics, 22(2), 262-312.

Robinson, S., \& Thierfelder, K. (2002). Trade liberalisation and regional integration: The search for large numbers. Australian Journal of Agricultural and Resource Economics, 46(4), 585- 604. https://doi.org/10.1111/1467-8489.t01-1-00057

Sahn, D., P. Dorosh, and S. Y. 1997. (2000). World Cereal Price Instability and a MarketBased Instrument for LDC Food Import Risk Management. Fishery Investigations Series.Ood Policy, 25(2), 189-209.

Stephen, J. (n.d.). PLANNING IN THE FUTURE : VIRTUAL ASSETS.

Wilson, N., \& J., C. (2007). Relations entre l'investissement direct étranger, les échanges et la politique commerciale : In Journal of Development Economics.

XU, B. (2000). Multinational Enterprise, technology, diffusion, and host country productivity growth",. In Journal of Development Economics, 62, 477-493.

Zhang, K. (2001a). Does foreign direct investment promote economic growth? Evidence from East Asia and Latin America. Contemporary Economic Policy, 19, 175-185.

Zhang, K. (2001b). Does foreign direct investment promote economic growth? Evidence from East Asia and Latin America. Contemporary Economic Policy, 19, 175-185. 